\title{
LAYANAN INFORMASI TENTANG PERKEMBANGAN PSIKOSEKSUAL YANG SEHAT OLEH GURU PEMBIMBING PADA SISWA KELAS XI IPA DI SEKOLAH MENENGAH ATAS NEGERI 1 BUNUT HILIR KABUPATEN KAPUAS HULU
}

\author{
Barriyati \\ Fakultas Ushuluddin, Adab dan Dakwah (FUAD) \\ Institut Agama Islam Negeri (IAIN) Pontianak \\ Email : barriyatiirwan@yahoo.com
}

\begin{abstract}
The purpose of this study was to obtain information and clarity about information services regarding healthy psychosexual development by the tutor teacher in class XI IPA students at Bunut Hilir 1 State High School. The method used in this research is descriptive method with the form of survey study. Based on the results of data analysis it was concluded that overall the implementation of information services about healthy psychosexual development in students of class XI Science in SMA 1 Bunut Hilir had gone well.

(Tujuan penelitian ini adalah untuk mendapatkan informasi serta kejelasan tentang layanan informasi mengenai perkembangan psikoseksual yang sehat oleh guru pembimbing pada siswa kelas XI IPA di Sekolah Menengah Atas Negeri 1 Bunut Hilir. Metode yang digunakan dalam penelitian ini adalah metode deskriptif dengan bentuk penelitian studi survey. Berdasarkan hasil analisis data disimpulkan bahwa secara keseluruhan pelaksanaan layanan informasi tentang perkembangan psikoseksual yang sehat pada siswa kelas XI IPA di SMA Negeri 1 Bunut Hilir sudah berjalan dengan baik).
\end{abstract}

Kata kunci: Layanan Informasi, Perkembangan Psikoseksual yang Sehat

\section{PENDAHULUAN}

Secara umum dapat dilihat bahwa siswa yang duduk di bangku Sekolah Menengah Atas (SMA), Sekolah Menengah Kejuruan (SMK), dan Madrasah Aliyah baik Negeri maupun Swasta, kadang kala tidak terlepas dari suatu permasalahan. Ada saja permasalahan yang terjadi pada siswa itu menyangkut perilaku, sikap dan perasaannya. Tidak hanya itu, remaja juga terkadang tidak dapat melaksanakan tugas perkembangannya dengan baik, baik itu seksualitas, emosi, bakat, kreativitas, moral dan hubungan sosial baik di sekolah maupun di masyarakat.

Berdasarkan masalah tersebut di atas yang terjadi pada remaja, tentunya tidak terlepas dari beberapa faktor penyebab yang terjadi selama masa pertumbuhan dan perkembangan sebelum masa remaja. Menurut Gerald Corey (E. Koeswara 2003:15) dalam Freud menyatakan bahwa: "Manusia di determinasi oleh kekuatan-kekuatan irasional, motivasi-motivasi tak sadar, 


\section{Barriyati}

Psikoseksual yang Sehat oleh Guru Pembimbing pada Siswa Kelas XI IPA di Sekolah Menengah Atas Negeri 1 Bunut Hilir Kabupaten Kapuas Hulu

kebutuhan-kebutuhan dan dorongan biologis dan naluriah, serta oleh peristiwaperistiwa psikoseksual yang terjadi selama 0-5 tahun". Berangkat dari teori psikoanalisis oleh Sigmund Frued, hal senada juga diungkapkan oleh Latipun (2001:70) yang mengungkapkan bahwa: "Pengalaman masa kanak-kanak sangat mempengaruhi pola kehidupan hingga dewasa".

Masa remaja merupakan masa peralihan (transisi) dari anak-anak menuju ke masa dewasa. Sebagaimana menurut pendapat Mappiare (dalam M. Asrori, 2005 : 14) bahwa: "Masa remaja berlangsung antara 12 tahun sampai dengan 21 tahun bagi wanita dan 13 tahun sampai dengan 22 tahun bagi pria". Pada usia tersebut, remaja sering di identikkan dengan masa seksualitas yang rasa keingintahuannya sangat besar. Sampai saat ini masalah seksualitas selalu menjadi topik yang menarik untuk dibicarakan. Hal ini dimungkinkan karena permasalahan seksual telah menjadi suatu hal yang sangat melekat pada diri manusia. Seksualitas tidak bisa dihindari oleh makhluk hidup, karena dengan seks makhluk hidup dapat terus bertahan menjaga kelestarian keturunannya.

Pada masa remaja rasa ingin tahu terhadap masalah seksual sangat penting dalam pembentukan hubungan baru yang lebih matang dengan lawan jenis. Padahal pada masa remaja informasi tentang masalah seksual sudah seharusnya mulai diberikan, agar remaja tidak mencari informasi dari orang lain atau dari sumbersumber yang tidak jelas atau bahkan keliru sama sekali. Tidak hanya masalah karakteristik seksual saja yang menarik pada masa remaja tapi yang sangat perlu diperhatikan adalah psikoseksual remaja tersebut. Kebanyakan remaja tidak sadar bahwa tingkah laku seksual yang terjadi dipengaruhi oleh dorongan-dorongan yang tidak disadarinya baik itu dari kejiwaan dan sikap mentalnya dalam tingkah laku seksual. Dalam ilmu psikologi hal tersebut dikenal dengan psikoseksual (psychosexual). Menurut Kartini Kartono 1981:406 (dalam Kamus Lengkap Psikologi oleh J.P. Charplin): "Psikoseksual adalah mencirikan suatu proses mental yang berasal dari dan didalam perkembangan seksual". Sedangkan secara umum seksual adalah sesuatu yang berkaitan dengan alat kelamin atau yang berhubungan dengan perkara-perkara hubungan intim antara laki-laki dengan perempuan. Pemberian informasi masalah seksual menjadi penting terlebih lagi mengingat remaja berada dalam potensi seksual yang aktif, karena berkaitan dengan dorongan seksual yang dipengaruhi hormon dan sering tidak memiliki 


\section{Al-Hikmah: Jurnal Dakwah, Volume 12, Nomar 2, Tahun 2018}

[P. 223-246]

informasi yang cukup mengenai aktivitas seksual mereka sendiri. Tentu saja hal tersebut akan sangat berbahaya bagi perkembangan jiwa remaja bila ia tidak memiliki pengetahuan dan informasi yang tepat.

Fakta menunjukkan bahwa sebagian besar remaja kita tidak mengetahui dampak dari perilaku seksual yang mereka lakukan, seringkali remaja sangat tidak matang untuk melakukan hubungan seksual terlebih lagi jika harus menanggung resiko dari hubungan seksual tersebut. Karena meningkatnya minat remaja pada masalah seksual dan sedang berada dalam potensi seksual yang aktif, maka remaja berusaha mencari berbagai informasi mengenai hal tersebut. Dari sumber informasi yang berhasil mereka dapatkan, pada umumnya hanya sedikit remaja yang mendapatkan seluk beluk seksual dari orang tuanya. Oleh karena itu remaja mencari atau mendapatkan dari berbagai sumber informasi yang mungkin dapat diperoleh, misalnya seperti membahas dengan teman di sekolah atau perguruan tinggi, dengan teman-teman bermain, sahabat, buku-buku tentang seks, media massa atau internet. Namun demikian pada kenyataannya remaja tidak sepenuhnya mendapatkan informasi tersebut. Bagi mereka hal yang menarik adalah membahas tentang perilaku dan karakteristik seksual tersebut tanpa mengetahui bahwa secara alamiah dan naluri, psikis mereka yang merasakan dan menentukan/menetapkan bagaimana sebenarnya dorongan itu ada. Oleh karena itu, remaja memerlukan bantuan yang serius dan sistematis guna memahami lebih luas apa yang belum remaja pahami tentang psikoseksual tersebut, sebab jika tidak dikhawatirkan akan mengarah kearah yang salah atau negatif.

Adapun salah satu upaya dalam membantu mengembangkan psikoseksual yang sehat bagi remaja adalah melalui kegiatan Bimbingan dan Konseling (BK) oleh guru pembimbing. Dalam kegiatan tersebut adanya bidang layanan yang salah satunya adalah layanan informasi. Diharapkan dengan pemberian informasi, remaja khususnya para siswa dapat menerima dan memahami berbagai informasi yang dapat dipergunakan sebagai bahan pertimbangan dan pengambilan keputusan untuk kepentingan peserta didik atau klien (Prayitno, 1998:36).

Pemberian informasi khususnya infomasi tentang psikoseksual tidak sepenuhnya diberikan oleh guru pembimbing di sekolah melainkan dapat bekerja sama dengan orang tua siswa. Memasuki dunia yang lebih banyak tantangan dan perubahan dari berkembangnya zaman, sudah selayaknya 
bila orang tua dan pendidik di sekolah bersikap lebih tanggap dalam menjaga dan mendidik anak dan remaja agar ekstra berhati-hati terhadap gejala-gejala sosial, terutama yang berkaitan dengan masalah seksual. Seiring perkembangan yang terjadi sudah saatnya pemberian penerangan dan pengetahuan masalah seksualitas pada anak dan remaja ditingkatkan. Pandangan sebagian besar masyarakat yang menganggap seksualitas merupakan suatu hal yang alamiah, yang nantinya akan diketahui dengan sendirinya setelah mereka menikah sehingga dianggap suatu hal tabu untuk dibicarakan secara terbuka, nampaknya secara perlahan-lahan harus diubah. Sudah saatnya pandangan semacam ini harus diluruskan agar tidak terjadi hal-hal yang tidak diinginkan dan membahayakan bagi anak dan remaja sebagai generasi penerus bangsa. Remaja yang hamil di luar nikah, aborsi, penyakit dan kelamin, adalah contoh dari beberapa kenyataan pahit yang sering terjadi pada remaja sebagai akibat pemahaman yang keliru mengenai seksualitas.

Jadi masa remaja akhir merupakan masa yang dianggap belum stabil tetapi pada masa ini remaja sudah dapat di anggap menentukan identitas diri, baik dan buruknya suatu perbuatan yang tentu saja tidak terlepas dari pola asuh orang tua sebagaimana selayaknya remaja inginkan yang tentunya berkaitan dari masa-masa perkembangan sebelum masa remaja.

Bertolak dari paparan tersebut, peneliti tertarik untuk mengkaji secara lebih mendalam dan memperoleh gambaran yang objektif mengenai pelaksanaan layanan informasi tentang perkembangan psikoseksual yang sehat oleh guru pembimbing pada siswa kelas XI IPA di SMA Negeri 1 Bunut Hilir. Adapun alasan penelitian ini dilakukan di SMA pada kelas XI IPA karena peneliti melihat bahwa pada usia siswa yang duduk dibangku SMA khususnya di kelas XI IPA adalah usia yang rawan pada remaja dalam keinginan rasa ingin tahu tentang seksualitas tanpa tahu bagaimana perkembangan psikoseksual secara sehat.

\section{Kajian Teori}

Psikoseksual berasal dari kata psiko/psikis dan seksual. psiko yang berarti sikap kejiwaan atau sikap mental sedangkan seksual berarti sesuatu yang berhubungan dengan seks atau kematangan libido (dorongan seksual). Menurut Kartini Kartono 1981:406 (dalam Kamus Lengkap Psikologi oleh J.P. Charplin): "Psikoseksual adalah mencirikan suatu proses mental yang berasal dari dan didalam perkembangan seksual". Sedangkan dalam Kamus Besar Bahasa Indonesia, "Psikoseksual yaitu 


\section{Al-Hikmah: Jurnal Dakwah, Volume 12, Nomar 2, Tahun 2018}

[P. 223-246]

berhubungan dengan berbagai gejala seks yang timbul karena faktor psikologis".

Berdasarkan dari definisi diatas, dapatlah dibuat kesimpulan bahwa pskoseksual merupakan suatu gamabaran tentang keadaan dan sikap mental atau kejiwaan kita dalam mengendalikan, mengatur, dan mengarahkan kematangan seksual. Seksualitas tidak bisa dihindari oleh makluk hidup terlebih lagi manusia, karena dengan seks makhluk hidup dapat terus bertahan menjaga kelestarian keturunannya.

Remaja baik putra maupun putri sesuai dengan masanya dengan mengalami pertumbuhan dan perkembangan fisik dan fsikis yang cukup cepat. Menurut E. Juhana Wijaya (1995: 24) menyatakan bahwa "Perkembangan psikoseksual adalah pertumbuhan, perubahan dan perkembangan yang terjadi pada anak yang berkaitan dengan seksualitas". Teori yang lebih jelas membahas tentang seksualitas yaitu terdapat pada Teori Psikoanalisis (Psychoanalysis Theory) dengan tokoh Sigmund Shlomo Freud. Menurut Sarlito W. Sarwono (http://www.allpsycho.com), Sigmund Freud mengatakan bahwa: "Seksualitas adalah faktor pendorong terkuat untuk melakukan sesuatu dan bahwa pada masa balita pun anak-anak mengalami ketertarikan dan kebutuhan seksual”.
Senada dengan hal tersebut Latipun (2001:68) dalam pandangan Freud menyatakan bahwa prinsip-prinsip psikoanalisis tentang hakikat manusia didasarkan pada asumsi, bahwa:

a. Prilaku pada masa dewasa berakar pada pengalaman masa kanak-kanak

b. Sebagian besar prilaku terintegrasi melalui proses mental yang tidak disadari

c. Pada dasarnya manusia memiliki kecendrungan yang sudah diperoleh sejak lahir, terutama kecendrungan mengembangkan diri melalui libido dan agresivitasnya

d. Secara umum prilaku manusia bertujuan dan mengarah pada tujuan untuk meredakan ketegangan, menolak kesakitan dan mencari kenikmatan

e. Kegagalan dalam pemenuhan kebutuhan seksual mengarah pada prilaku neurosis

f. Pengalaman tunggal hanya dapat dipahami dengan melihat keseluruhan pengalaman seseorang. Masa lalu, masa kini dan masa yang akan datang adalah saling berhubungan dalam satu kesatuan. Apa yang yang terjadi pada seseorang pada saat ini dihubungkan dengan sebab-sebab dimasa lampaunya dan memotivasi untuk mencapai tujuantujuan dimasa yang akan datang 


\section{Barriyati}

Psikoseksual yang Sehat oleh Guru Pembimbing pada Siswa Kelas XI IPA di Sekolah Menengah Atas Negeri 1 Bunut Hilir Kabupaten Kapuas Hulu

g. Latihan pengalaman dimasa kanakkanak berpengaruh penting pada prilaku masa dewasa dan diulangi dalam transferensi selama proses terapi.

Selanjutnya Frued menurut John Mcleod (dalam A.K Anwar 2006:94) menyatakan: "Pengalaman dimasa kanakkanak mempengaruhi kepribadian di usia dewasa. Terjadinya pengaruh tersebut dapat terjadi dengan cara-cara tertentu melalui bekerjanya pikiran bawah sadar". Ketidaksadaran ini merupakan bagian dari kehidupan mental seseorang yang berada diluar kesadaran. Dalam pandangannya, Freud membagi tiga pikiran manusia kedalam wilayah Id (naluri biologis), Ego (pikiran) dan Super ego (nilai sosial dan moral). Selanjutnya Gerald Corey (1989:12) menyatakan bahwa: "Human are viewed as energy systems. The dynamics of personality consist of the ways in which psychic energy is distributed to the id, ego, and superego" artinya: manusia adalah sebagai beberapa sistem energi. Kepribadian dinamis terdiri dari jalan didalam energi psikis (batin/naluri) dengan menghasilkan id, ego dan superego.

Dengan demikian, pandangan psikoanalisis ini memberikan implikasi yang sangat luas terhadap konseling dan psikoterapi khususnya dalam aspek tujuan penyelesaian masalah yang hendak dicapai dalam prosedur yang telah dikembangkan.

Berangkat dari penjelasan diatas, pengertian terhadap perkembangan psikoseksual mempengaruhi perkembangan identias seksual. Penanganan yang salah dapat mengembangkan sikap-sikap yang tidak diinginkan, bahkan deviasi seksual karena pandangan dalam teori tersebut menegaskan bahwa pengalaman masa kanak-kanak sangat mempengaruhi pola kehidupan hingga dewasa. Dalam pandangan Freud secara genetik, menurut Latipun (2001:63) mengungkapkan bahwa perkembangan kepribadian berkembang melalui beberapa tahap yaitu:

a. Fase oral (0-1 tahun).

b. Fase anal (1-3 tahun).

c. Fase falik (3-6 tahun).

d. Fase laten (6-11 tahun).

e. Fase genital (11-19 tahun dan selama masa pubertas).

Berikut penjelasan tahap perkembangan kepribadian mulai dari bayi baru lahir sampai usia remaja:

a. Fase oral (0-1 tahun). Pada fase ini anak berkembang berdasarkan pengalaman kenikmatan erotik pada daerah mulut. Kepuasan anak melalui tindakan mengisap akan mempengaruhi kehidupan dimasa dewasanya. Akibat kegagalan dari fase ini adalah anak 
tidak mempu berhubungan dengan orang lain, tidak dapat mencintai dan mempercayai orang lain, terjadinya isolasi dan penarikan diri dari lingkungan sosial.

b. Fase anal (1-3 tahun). Perkembangan pada fase ini berpusat pada kenikmatan daerah anus. Anak mulai belajar untuk mengendalikan buang air, termasuk untuk belajar menerima perasaanperasaan yang tidak menyenangkan serta pengalaman memperoleh raksi dari orang tua yang berhubungan dengan buang air. Selama fase anal, peran latihan buang air (toilet training) sangat penting untuk belajar disiplin dan moral. Anak mulai belajar mandiri, memiliki kekuatan pribadi, otonomi, mengakui dan menangani perasaan yang negatif. Akibat kegagalan dari fase ini adalah anak tidak peduli dengan lingkungan.

c. Fase falik (3-6 tahun). Pada fase ini pusat kenikmatan berpusat pada alat kelamin, yaitu penis pada anak laki-laki dan klitoris pada anak perempuan. Pada fase ini anak mulai belajar menerima perasaan-perasaan seksualnya sebagai hal yang alamiah dan belajar memandang tubuhnya sendiri secara sehat. Mereka mulai mengembangkan hati nurani, dan mengenal standar moral baik dan buruk serta kritis terhadap perlakuan orang tua yang dipandang tidak tepat. Pada fase ini terjadi Oedipus complex (perasaan mencintai ibunya pada anak laki-laki) dan electra complex (perasaan mencintai ayahnya pada anak perempuan). Karena itu anak laki-laki berusaha mengidentifikasi pada ayahnya dan begitu pula pada anak perempuan. Akibat kegagalan dari fase ini adalah dapat kebingungan akan peran seks secara wajar, dan dalam menemukan standar moral yang tepat.

d. Fase laten (6-11 tahun). Pada fase ini juga disebut tahap pragenital. Tahap fase ini terjadi perhentian perkembangan. Sepanjang masa ini anak menjalankan tugas-tugas belajar. Anak melihat anak lain sebagai teman yang dapat dikagumi, ditakuti, disayang, dibenci, teman bersaing, atau anak dapat mengidentifikasi diri dengan temannya. Pada fase ini anak harus memiliki potensi untuk rasa kebersamaan. Anak lelaki dan perempuan bermain bersama. Kegagalan fase ini membuat anak rendah diri, tak bergairah untuk belajar atau bekerja, tidak dapat bersosialisasi.

e. Fase genital (11-19 tahun dan selama masa pubertas). pada fase ini, Seks sekunder berkembang pesat, anak lelaki mulai mimpi basah dan anak perempuan mengalami menstruasi. Anak 
berkembang menjadi pemberontak, sulit diatur, menuntut terhadap orang tua dan mempunyai pendapat sendiri. Pada masa ini remaja putra malu berjalan dengan ibunya, ia menolak dicium orang tua. Ini menunjukkan anak ingin melepaskan diri dari orang tua, dari ikatan keluarga. Teman-teman sebaya menjadi penting dan hubungan ini memberi rasa aman dan kepastian pada remaja. Remaja mencari pengalaman heteroseksual (pacaran). Dorongan dan minat seks berkembang dengan pesat, misalnya : mengintif orang mandi, melihat gambar porno, onani, dan menggoda lawan jenis. Kegagalan fase ini membuat remaja bingung akan dirinya yang tercetus dalam pertanyaan: "Siapakah aku"?. Fase ini seringkali dihubungkan dengan kesalahankesalahan pada fase sebelumnya.

Sejalan dengan perkembangan kepribadian yang telah ditentukan oleh setiap tahap-tahap masa perkembangan mulai dari bayi sampai remaja, perkembangan psikoseksual pada remaja tampak pula pada perubahan pertumbuhan fisik. Dalam hal ini terdapat keterkaitan antara perkembangan dan pertumbuhan yang sejalan dan saling berhubungan selama masa perubahan pada manusia.
Senada dengan hal tersebut, menurut Asrori (2005:17) mengatakan bahwa:

Pertumbuhan yang terjadi sebagai perubahan individu lebih mengacu dan menekankan pada aspek perubahan fisik (berat, panjang, tinggi, tulang dan otot menjadi lebih kuat, lingkaran tubuh menjadi besar dan organ tubuh lebih kelihatan sempurna) dengan istilah kata lain perubahan fisiologis yang bersifat progresif dan bersifat continue serta berlangsung pada periode tertentu. Sedangkan perkembangan lebih mengacu pada perubahan karakteristik yang khas dari gejala psikologis. Hasil dari perubahan tersebut sering dikenal dengan istilah kematangan.

Terjadinya pertumbuhan dan perkembangan psiko/psikis remaja tentu saja mempengaruhui pula perubahan dan perkembangan psikoseksualnya, yakni berkaitan dengan kematangan libido atau seksualitasnya yang ditandai dengan terjadinya menstruasi bagi remaja putri dan mimpi basah pada remaja putra. Remaja dapat digambarkan secara umum yaitu seseorang yang berada pada usia sekolah menengah, dengan arti lain remaja adalah masa peralihan antara anak-anak menuju masa dewasa.

Seksual sangat identik pada masa remaja. Pengertian seksual secara umum 


\section{Al-Hikmah: Jurnal Dakwah, Volume 12, Nomar 2, Tahun 2018}

[P. 223-246]

adalah sesuatu yang berkaitan dengan alat kelamin atau hal-hal yang berhubungan dengan perkara-perkara hubungan intim antara laki-laki dengan perempuan. Karakter seksual masing-masing jenis kelamin memiliki spesifikasi yang berbeda. Menurut Zainun Mu`tadin, dalam Microsoft Encarta Encyclopedia 2002 (http://www.pscyco.com) bahwa:

Sexual characteristics are divided into two types. Primary sexual characteristics are directly related to reproduction and include the sex organs (genitalia). Secondary sexual characteristics are attributes other than the sex organs that generally distinguish one sex from the other but are not essential to reproduction, such as the larger breasts characteristic of women and the facial hair and deeper voices characteristic of men.

Selanjutnya menurut E. Juhana Wijaya (1995:24) mengungkapkan bahwa: Perkembangan psikoseksual yang tampak pada remaja putra terlihat dari kegiatankegiatannya seperti mau bekerja sama dengan kaum wanita, menjalin persahabatan dengan lawan jenis, membaca buku tentang seks, menonton film yang bercerita tentang cinta, mencoba-coba untuk pacaran. Sedangkan pada remaja putri tampak jelas dari sikap, perilaku, dan kegiatan-kegiatannya seperti suka berdandan, merias diri, tidak malu bergaul dengan pria, membaca buku yang mengisahkan petualangan cinta dan seks, mulai berani berpacaran dan menonton film tentang cinta.

Seiring dengan pertumbuhan primer dan sekunder pada remaja ke arah kematangan yang sempurna, muncul juga hasrat dan dorongan untuk menyalurkan keinginan seksualnya. Hal tersebut merupakan suatu yang wajar karena secara alamiah dorongan seksual ini memang harus terjadi untuk menyalurkan kasih sayang antara dua insan, sebagai fungsi pengembangbiakan dan mempertahankan keturunan.

Dari beberapa pendapat para ahli diatas, maka dapat disimpulkan bahwa pada jenjang atau tingkat kehidupan dalam proses pertumbuhan, kematangan dan perkembangan masa remaja telah mempu menetapkan identitasnya dalam mengambil dan menentukan tugas-tugas perkembangan menuju kearah kematangan serta dapat menjalankan perannya dari pengalaman-pengalaman yang baru ia dapatkan.

Bertentangan dari penjelasan diatas, bahwa tidak semua remaja dapat melaksanakan tugas perkembangannya dengan baik. Apabila remaja sudah mengenal seks maka yang sering terjadi adalah penyimpangan prilaku seksual. Secara umum perilaku seksual adalah segala tingkah laku yang didorong oleh hasrat seksual, baik dengan lawan jenis 
maupun sesama jenis. Bentuk-bentuk tingkah laku ini dapat beraneka ragam, mulai dari perasaan tertarik hingga tingkah laku berkencan, bercumbu dan senggama. Obyek seksual dapat berupa orang, baik sejenis maupun lawan jenis, orang dalam khayalan atau diri sendiri. Sebagian tingkah laku ini memang tidak memiliki dampak, terutama bila tidak menimbulkan dampak fisik bagi orang yang bersangkutan atau lingkungan sosial. Tetapi sebagian perilaku seksual (yang dilakukan sebelum waktunya) justru dapat memiliki dampak psikologis yang sangat serius, seperti rasa bersalah, depresi, marah, dan agresi.

Menurut Mari Sumarti (1991:27) berbagai perilaku seksual pada remaja yang belum saatnya untuk melakukan hubungan seksual secara wajar antara lain dikenal sebagai:

a. Masturbasi atau onani yaitu suatu kebiasaan buruk berupa manipulasi terhadap alat genital dalam rangka menyalurkan hasrat seksual untuk pemenuhan kenikmatan yang seringkali menimbulkan goncangan pribadi dan emosi.

b. Berpacaran dengan berbagai perilaku seksual yang ringan seperti sentuhan, pegangan tangan sampai pada ciuman dan sentuhan-sentuhan seks yang pada dasarnya adalah keinginan untuk menikmati dan memuaskan dorongan seksual.

c. Berbagai kegiatan yang mengarah pada pemuasan dorongan seksual yang pada dasarnya menunjukan tidak berhasilnya seseorang dalam mengendalikannya atau kegagalan untuk mengalihkan dorongan tersebut ke kegiatan lain yang sebenarnya masih dapat dikerjakan.

Dengan demikian dorongan atau hasrat untuk melakukan hubungan seksual selalu muncul pada remaja, oleh karena itu bila tidak ada penyaluran yang sesuai (menikah) maka harus dilakukan usaha untuk memberi pengertian dan pengetahuan mengenai hal tersebut.

Pada masa remaja diharapakan dapat bersikap, berpikir, dan bertingkah laku yang sesuai atau cocok dengan tuntutan lingkungannya, serta eksistensinya sebagai remaja yang disebut sebagai tugas-tugas perkembangan. Arti tugas-tugas perkembangan adalah pertunjuk-petunjuk yang memungkinkan seseorang mengerti atau memahami apa yang diharapkan oleh masyarakat dan lingkungannya serta tantangan apa dan bagaimana yang diharapkan pada masa yang akan datang, sehingga dapat hidup lebih baik. 
Dari penjelasan diatas, dapatlah disimpulkan bahwa remaja harus dapat memahami dengan baik dan benar selama masa perkembangan tugas-tugas remaja tersebut khususnya perkembangan psikoseksual dan diharapkan remaja dapat berfikir terlebih dahulu sebelum melakukan tingkahlaku yang menyimpang.

\section{Karakteristik Perkembangan Psikosek- sual Yang Sehat}

Karakteristik

perkembangan psikoseksual remaja itu semakin bertambah usia, pengetahuan dan pengalaman maka semakin matang pula psikoseksual yang ditandai dengan semakin dewasanya dalam menyalurkan dorongan libido, tidak malu lagi untuk berpacaran, membicarakan hubungan seksualitas sesama teman, menonton film dan membaca novel yang berceritakan petualangan cinta dan seks. Pada masa inilah merupakan masa-masa yang berbahaya karena rasa keingintahuan dan keinginan untuk merasakan akan mengarah ke hal-hal yang negatif seperti penyimpangan seksual dan melakukan hubungan seks diluar nikah, melakukan onani dan mastrubasi yang sebenarnya bertentangan dengan nilai-nilai dan normanorma kehidupan yang berlaku dimasyarakat.
Dari penjelasan di atas hendaknya para remaja khususnya remaja putri, harus berusaha tanggap, mengantisipasi dan mengendalikan perkembangan psikoseksual secara baik, benar dan sehat sesuai dengan nilai dan norma yang berlaku dalam masyarakat sebab jika penyimpangan itu terjadi yang paling berat menanggung dan menghadapi akibat dari perbuatan itu adalah remaja putri seperti kehamilan diluar nikah. Para remaja harus menyadari bahwa pengertian seksualitas itu tidak identik dengan hubungan seks semata melainkan mengandung pengertian yang lebih luas. Dengan kata lain perkembangan psikosesksual itu dapat diikuti, dikendalikan dan diarahkan pada kegiatan-kegiatan yang positif dan produktif dengan tujuan dan harapan bahwa dorongan libido tersebut dapat tersalurkan secara baik sehat.

\section{Adapun karakteristik perkem-} bangan psikoseksual yang sehat dapat dilakukan dengan cara pemberian informasi dan memperkenalkan tentang pendidikan seksual yang baik dan sehat sejak dini pada remaja. Menurut Sarlito Wirawan Sarwono (2006:190), secara umum: Pendidikan seksual adalah suatu informasi mengenai persoalan seksualitas manusia yang jelas dan benar, yang meliputi proses terjadinya pembuahan, kehamilan sampai kelahiran, tingkah laku 


\section{Barriyati}

Psikoseksual yang Sehat oleh Guru Pembimbing pada Siswa Kelas XI IPA di Sekolah Menengah Atas Negeri 1 Bunut Hilir Kabupaten Kapuas Hulu

seksual, hubungan seksual, dan aspekaspek kesehatan, kejiwaan dan kemasyarakatan.

Sejalan dengan hal tersebut, menurut Singgih, D. Gunarsa (1992:90), "Penyampaian materi pendidikan seksual ini seharusnya diberikan sejak dini ketika anak sudah mulai bertanya tentang perbedaan kelamin antara dirinya dan orang lain, berkesinambungan dan bertahap, disesuaikan dengan kebutuhan dan umur anak serta daya tangkap anak". Dalam hal ini pendidikan seksual idealnya diberikan pertama kali oleh orangtua di rumah, mengingat yang paling tahu keadaan anak adalah orangtuanya sendiri. Tetapi sayangnya di Indonesia tidak semua orangtua mau terbuka terhadap anak di dalam membicarakan permasalahan seksual. Selain itu tingkat sosial ekonomi maupun tingkat pendidikan yang heterogen di Indonesia menyebabkan ada orang tua yang mau dan mampu memberikan penerangan tentang seks tetapi lebih banyak yang tidak mampu dan tidak memahami permasalahan tersebut.

Pendidikan seksual selain menerangkan tentang aspek-aspek anatomis dan biologis juga menerangkan tentang aspek-aspek psikologis dan moral. Pendidikan seksual yang benar harus memasukkan unsur-unsur hak asasi manusia. Juga nilai-nilai kultur dan agama diikutsertakan sehingga akan merupakan pendidikan akhlak dan moral juga. Beberapa ahli mengatakan pendidikan seksual yang baik harus dilengkapi dengan pendidikan etika, pendidikan tentang hubungan antar sesama manusia baik dalam hubungan keluarga maupun di dalam masyarakat. Juga dikatakan bahwa tujuan dari pendidikan seksual adalah bukan untuk menimbulkan rasa ingin tahu dan ingin mencoba hubungan seksual antara remaja, tetapi ingin menyiapkan agar remaja tahu tentang seksualitas dan akibat-akibatnya bila dilakukan tanpa mematuhi aturan hukum, agama dan adat istiadat serta kesiapan mental dan material seseorang.

Penjabaran tujuan pendidikan seksual dengan lebih lengkap di jabarkan oleh Zainun Mu`tadin, dalam Microsoft Encarta Encyclopedia 2002 (http://www.pscyco.com) bahwa: sebagai berikut :

a. Memberikan pengertian yang memadai mengenai perubahan fisik, mental dan proses kematangan emosional yang berkaitan dengan masalah seksual pada remaja.

b. Mengurangi ketakutan dan kecemasan sehubungan dengan perkembangan dan penyesuaian seksual (peran, tuntutan dan tanggungjawab) 


\section{Al-Hikmah: Jurnal Dakwah, Volume 12, Nomar 2, Tahun 2018}

[P. 223-246]

c. Membentuk sikap dan memberikan pengertian terhadap seks dalam semua manifestasi yang bervariasi

d. Memberikan pengertian bahwa hubungan antara manusia dapat membawa kepuasan pada kedua individu dan kehidupan keluarga.

e. Memberikan pengertian mengenai kebutuhan nilai moral yang esensial untuk memberikan dasar yang rasional dalam membuat keputusan berhubungan dengan perilaku seksual.

f. Memberikan pengetahuan tentang kesalahan dan penyimpangan seksual agar individu dapat menjaga diri dan melawan eksploitasi yang dapat mengganggu kesehatan fisik dan mentalnya.

g. Untuk mengurangi prostitusi, ketakutan terhadap seksual yang tidak rasional dan eksplorasi seks yang berlebihan.

h. Memberikan pengertian dan kondisi yang dapat membuat individu melakukan aktivitas seksual secara efektif dan kreatif dalam berbagai peran, misalnya sebagai istri atau suami, orang tua, anggota masyarakat.

Jadi dari penjelasan diatas dapat disimpulkan bahwa tujuan pendidikan seksual adalah untuk membentuk suatu sikap emosional yang sehat terhadap masalah seksual dan membimbing anak dan remaja ke arah hidup dewasa yang sehat dan bertanggung jawab terhadap kehidupan seksualnya. Hal ini dimaksudkan agar mereka tidak menganggap seks itu suatu yang menjijikan dan kotor. Tetapi lebih sebagai bawaan manusia, yang merupakan anugrah Tuhan dan berfungsi penting untuk kelanggengan kehidupan manusia, dan supaya anak-anak itu bisa belajar menghargai kemampuan seksualnya dan hanya menyalurkan dorongan tersebut untuk tujuan tertentu (yang baik) dan pada waktu yang tertentu saja.

Dalam hal ini, selain remaja penting mengetahui terlebih dahulu tentang pendidikan seks, adapun karakteristik caracara yang baik dan positif dalam situasi dan kegiatan ilmiah umumnya tidak memberi peluang pada remaja untuk mengembangkan sikap dan perilaku negatif seperti yang diungkapkan oleh Latipun (1995:25) yaitu:

a. Mengikuti dan menyalurkannya dalam kegiatan-kegiatan yang positif seperti OSIS, pramuka, PMR, seminar, diskusi ilmiah, kesenian, dan olah raga.

b. Berusaha hidup disiplin, tertib dan mematuhi norma-norma kehidupan yang berlaku didalam masyarakat

c. Dalam berpacaran diharapkan dapat mengendalikan agar tidak melakukan 


\section{Barriyati}

Psikoseksual yang Sehat oleh Guru Pembimbing pada Siswa Kelas XI IPA di Sekolah Menengah Atas Negeri 1 Bunut Hilir Kabupaten Kapuas Hulu

penyimpangan dan melanggar nilai serta norma kehidupan

d. Aktif dan kratif mengikuti penyuluhan tentang seks baik itu seminar, diskusi maupun debat jejak pendapat.

Jadi dalam karakteristik perkembangan psikoseksual hendaknya tidak dilakukan dengan satu cara saja melainkan sebagai remaja harusnya dapat lebih berinisiatif dalam perkembangan dirinya yang lebih baik dan tidak mengarah kearah hal yang menyimpang.

\section{Faktor-Faktor Yang Mempengaruhi Perkembangan Psikoseksual Yang Sehat.}

Perkembangan psikoseksual yang sehat sangat dipengaruhi oleh beberapa faktor, baik itu faktor internal (dalam diri individu) dan faktor eksternal (dari luar diri individu). Adapun faktor internal yang mempengaruhi perkembangan psikoseksual yang sehat adalah individu (siswa) tersebut sudah dapat memahami dan menyadari bahwa tingkah laku psikoseksual yang dilakukan dengan paksaan dan dengan tidak sewajarnya tersebut bertentangan dengan norma, moral ataupun aturan yang berlaku khususnya dalam norma agama. Menurut M. Bukhori (1994:2) menyatakan bahwa: "Untuk menghindari hal-hal yang tidak diinginkan, perlunya diterapkan moral dan norma agama dalam perilaku seksual. jika moral dan norma agama diterapkan dalam seks maka agama akan membimbing tingkah laku hubungan seksual yang baik sejalan dengan tuntunan agama".

Sedangkan faktor eksternal yang mempengaruhi perkembangan psikoseksual yang sehat adalah:

a. Pemberian informasi tentang pendidikan seksual dari orang tua

Dalam masalah ini, pemberian informasi khususnya infomasi tentang psikoseksual tidak sepenuhnya diberikan oleh guru pembimbing disekolah melainkan dapat juga diberikan oleh orang tua remaja atau siswa tersebut. Menurut M. Bukhori (1994:6) menyatakan bahwa: "Salah satu faktor psikoseksual yang baik, aman dan sehat adalah adanya penerangan tentang pendidikan seksual lebih dini dari orang tua agar anak tidak mencari informasi yang salah, menyimpang dan tidak sesuai dengan kaidah agama”. Sedangkan menurut Singgih, D. Gunarsa (1992:90), "Penyampaian materi pendidikan seksual ini seharusnya diberikan sejak dini oleh orang terdekat (orang tua) ketika anak sudah mulai bertanya tentang perbedaan kelamin antara dirinya dan orang lain, 


\section{Al-Hikmah: Jurnal Dakwah, Volume 12, Nomor 2, Tahun 2018}

[P. 223-246]

berkesinambungan dan bertahap, disesuaikan dengan kebutuhan dan umur anak serta daya tangkap anak".

Memasuki dunia yang lebih banyak tantangan dan perubahan dari berkembangnya zaman, sudah selayaknya bila orang tua dan kaum pendidik bersikap lebih tanggap dalam menjaga dan mendidik anak dan remaja agar ekstra berhati-hati terhadap gejalagejala sosial, terutama yang berkaitan dengan masalah seksual, karena dalam hal ini pendidikan seksual idealnya diberikan pertama kali oleh orangtua di rumah, mengingat yang paling tahu keadaan anak adalah orangtuanya sendiri.

b. Melakukan dan melaksanakan hal positif sesama teman disekolah

Melakukan hal positif sesama teman disekolah dapat dilakukan seperti mengikuti dan menyalurkannya dalam kegiatan-kegiatan yang positif. Menurut Latipun (1995:25) bahwa:

Mengikuti dan menyalurkannya dalam kegiatan-kegiatan yang positif seperti OSIS, pramuka, PMR, seminar, diskusi ilmiah, kesenian, dan olah raga serta aktif dan kratif mengikuti penyuluhan tentang seks baik itu seminar, diskusi maupun debat jejak pendapat yang berhubungan dengan perkembangan remaja yang sehat dapat menghambat perilaku negatif dalam perkembambangan remaja.

c. Perilaku Pacaran yang sehat

Untuk mencapai bentuk pacaran yang sehat, seharusnya pada masa remaja sangat perlu untuk diberikan bimbingan yang mengarahkan mereka pada perilaku pacaran yang sehat. Menurut Henry Cloud dan John Thownsend (2002:2) mengatakan bahwa : "Perilaku berpacaran yang sehat, yakni hasrat didasari oleh cinta kasih, dan melupakan unsur seks". Selanjutnya menurut Zarfiel Tapal (1997:62) mengatakan bahwa: "Pacaran sehat, berarti sehat fisik, psikologis, dan sosial".

Dalam pengaruh eksternal perkembangan psikoseksual yang sehat bagi siswa, berpacaran merupakan salah satu faktor yang terpenting karena dalam perilaku pacaran pada penerapannya banyak pasangan remaja melakukan hal-hal yang negatif dan tidak sesuai dengan norma atau aturan yang ada. Menurut M. Asrori (2005:29) "Remaja pada umumnya memiliki rasa ingin tahu yang tinggi sehingga seringkali ingin mencoba-coba, menghayal, dan merasa gelisah, serta berani melakukan pertentangan jika dirinya merasa disepelekan atau tidak 


\section{Barriyati}

Psikoseksual yang Sehat oleh Guru Pembimbing pada Siswa Kelas XI IPA di Sekolah Menengah Atas Negeri 1 Bunut Hilir Kabupaten Kapuas Hulu

dianggap". Dalam berpacaran diharapkan setiap pasangan remaja dapat mengendalikan agar tidak melakukan penyimpangan dan melanggar nilai serta norma kehidupan.

Dari penjelasan di atas, dapatlah disimpulkan bahwa faktor internal dan ekternal sangat mempengaruhi dari perkembangan psikoseksual yang sehat karena pada hakikatnya tidak semua remaja (siswa) dapat melaksanakan tugas perkembangannya dengan baik dan benar. Semua itu tergantung faktor yang mempengaruhi kehidupan remaja itu sendiri.

\section{Dampak Negatif Perkembangan}

\section{Psikoseksual Yang Tidak Sehat}

Secara umum anak yang berusia 12 sampai dengan 19 sedang berada dalam pertumbuhan yang mengalami masa remaja. Masa remaja termasuk masa yang sangat menentukan karena pada masa ini anak banyak mengalami banyak perubahan pada psikis dan fisiknya. terjadinya perubahan kejiwaan menimbulkan kebingungan dikalangan remaja sehingga masa ini lebih dikenal sebagai periode strum and drang. Adapun penyebabnya karena remaja mengalami penuh gejolak emosi dan tekanan jiwa sehingga mudah menyimpang dari aturan dan norma sosial yang berlaku di masyarakat. Menurut Soerjono Soekanto (1996:10), menyatakan bahwa:

Keinginan-keinginan pribadi yang tidak terpenuhi mungkin akan menimbulkan keinginan-keinginan untuk menyimpang dari norma-norma yang berlaku, oleh karena norma-norma tersebut kurang mampu untuk memberikan peluang bagi tercapainya keinginan pribadi. Maka kemungkinan akan timbul tingkah laku yang menyimpang atau yang dinamakan deviant behavior.

Dalam perkembangan psikoseksual tidak semua remaja dapat melaksanakannya dengan baik dan sempurna karena psikoseksual merupakan bagian dari naluri setiap individu. Perkembangan psikoseksual yang sehat dalam masalah ini dapat diartikan sehat secara perilaku, moral dan norma yang berlaku dimasyarakat. Sebaliknya psikoseksual yang tidak sehat merupakan bagian dari penyimpangan atau larangan. Adapun bentuk penyimpangan dalam psikoseksual menurut Soerjono Soekanto (1996:48):
a. Onani atau mastrubasi
b. Pacaran yang tidak sehat
c. Homoseks dan lesbian
d. Pelecehan Seksual (sodomi)
e. Pemerkosaan. 


\section{Al-Hikmah: Jurnal Dakwah, Volume 12, Nomor 2, Tahun 2018}

[P. 223-246]

Dari bentuk penyimpangan dari tugas perkembangan psikoseksual yang tidak sehat, dapat dijabarkan secara jelas sebagai berikut:

a. Onani atau masturbasi

Masturbasi sering disebut juga dengan onani yang berasal dari bahasa latin, yaitu masturbatio. Mastur berarti tangan sedangkan batio berarti menodai. Jadi onani atau mastrubasi yaitu suatu kebiasaan buruk berupa manipulasi terhadap alat genital dalam rangka menyalurkan hasrat seksual untuk pemenuhan kenikmatan yang seringkali menimbulkan goncangan pribadi dan emosi.

Menurut J.P Chaplin dalam Kamus Lengkap Psikologi oleh Kartini Kartono (2001:289) Onani atau mastrubasi adalah: "Induksi satu keadaan penegangan alat kelamin dan pencapaian orgasme lewat rangsangan dengan tangan atau rangsangan mekanis. Selanjutnya menurut Khuslan Haludhi dan Adurrohim Sa id (2004:148), menyatakan bahwa: "Masturbasi atau onani berarti pemuasan seksual pada diri sendiri dengan menggunakan tangan”. Kebiasaan masturbasi pada remaja dapat menimbulkan problem psikologis berupa kebingungan dan rasa tidak tenang dari dampak negatif yang dilakukannya.

b. Pacaran yang tidak sehat

Perilaku pacaran yang tidak sehat menurut Eka sabirin (www.pkbijatengpacaran.com) meliputi: "Tidak sehat secara fisik, emosional, sosial dan seksual". Selanjutnya menurut Mari Sumarti (1991:27) mengungkapkan bahwa salah satu bentuk pacaran yang tidak sehat yaitu: "Berpacaran dengan berbagai perilaku seksual yang ringan seperti sentuhan, pegangan tangan sampai pada ciuman dan sentuhansentuhan seks yang pada dasarnya adalah keinginan untuk menikmati dan memuaskan dorongan seksual”.

c. Homoseks dan lesbian

Homoseks adalah pemuasan atau penyaluran nafsu seks antara sesama pria. Sedangkan lesbian adalah pemuasan nafsu seks antara sesama wanita. Keduanya merupakan perbuatan atau perilaku yang dilarang baik dalam norma agama dan norma susila dalam masyarakat karena bertentangan dengan kodrat sebagai manusia. Menurut J.P Chaplin dalam Kamus Lengkap Psikologi oleh Kartini Kartono (2001:228) mengungkapkan: "Homoseksual berarti hubungan seksual antara anggota 


\section{Barriyati}

Psikoseksual yang Sehat oleh Guru Pembimbing pada Siswa Kelas XI IPA di Sekolah Menengah Atas Negeri 1 Bunut Hilir Kabupaten Kapuas Hulu

jenis kelamin yang sama serta daya tarik seksual sesama anggota jenis yang sama" sedangkan lesbian menurut J.P Chaplin dalam Kamus Lengkap Psikologi oleh Kartini Kartono (2001:275), bahwa: "Lesbianisme adalah homoseksualitas di kalangan wanita".

d. Pelecehan Seksual (sodomi)

Kita sering mendapat berita tentang perilaku sodomi di media cetak ataupun media elektronik. Salah satu contoh di Koran Kompas (11 Mei 2003) memberitakan seorang remaja usia 18 tahun melakukan sodomi terhadap lima bocah usia 11 hingga 15 tahun, tetangganya sekaligus teman mengajinya. Kasus sodomi kembali diberitakan Kompas (17 Mei 2003), yakni yang dilakukan oleh tersangka berusia 23 tahun terhadap korban berusia 7 tahun sebanyak 6 kali selama tiga bulan terakhir. Namun sekarang ada perluasan makna sodomi yaitu berhubungan seksual lewat dubur dan membunuh pasangannya untuk mendapatkan kepuasan. Menurut J.P Chaplin dalam Kamus Lengkap Psikologi oleh Kartini Kartono (2001:473) sodomi adalah: "Hubungan seksual antara laki-laki lewat anus atau dubur serta hubungan kelamin dengan binatang". e. Pemerkosaan

Perkosaan adalah perilaku menyimpang yang merasa mendapat kepuasan seksual dengan cara memaksa orang lain untuk melakukan hubunan seksual. Perkosaan dapat terjadi pada orang yang di kenal atau tidak dikenal. Hal itu sangat bertentangan dengan norma susila dan tidak sejalan dengan hubungan sosial manusia. Salah satu contoh Harian Pontianak Post (23 Februari 2006) memberitakan bahwa seorang kakek berusia 57 tahun divonis 8 tahun penjara karena memerkosa dua anak perempuan usia 12 dan 13 tahun.

Selanjutnya menurut Khuslan Haludhi dan Adurrohim Sa`id (2004:148), mengungkapkan bahwa: "Bentuk perkembangan psikoseksual yang tidak sehat atau negatif sering dikenal dengan perilaku asusila". Asusila adalah perbuatan yang melanggar norma sosial dan norma agama. Umumnya perbuatan asusila dikaitkan dengan perbuatan yang mengarah pada penyimpangan seksual. Penyimpangan seksual dapat diartikan sebagai kebutuhan sosial tentang biologis dengan cara hubungan kelamin yang menyimpang dari ketentuan syariat. Adapun bentuk 


\section{Al-Hikmah: Jurnal Dakwah, Volume 12, Nomar 2, Tahun 2018}

[P. 223-246]

penyimpangan itu menurut Khuslan Haludhi dan Adurrohim Sa`id (2004:148) meliputi: zina atau heteroseksual, Free seks, Semenleven, Voyeurisme, Fethisisme, dan Pelecehan seks.

Dari uraian di atas, bentuk perkembangan psikoseksual yang tidak sehat atau negatif sering dikenal dengan perilaku asusila dapat di jelaskan sebagai berikut:

a. Zina atau heteroseksual

Zina adalah melakukan hubungan kelamin (persetubuhan) lakilaki dan perempuan di luar pernikahan yang sah. Selain perzinahan sering dikenal dengan istilah pelacuran. Keduanya juga dikenal dengan istilah heteroseksual, yaitu orang yang melakukan hubungan seksual normal terhadap lawan jenis tetapi praktiknya dilakukan diluar ikatan pernikahan.

b. Free seks

Pengertian free seks dalam arti luas yaitu menghalalkan segala cara dan tidak terbatas pada kelompok tertentu. Mereka tidak berpegang teguh pada susila atau nilai-nilai manusiawi. Suatu saat hubungan dengan orang lain (kumpul kebo) dan dilain waktu mereka juga menggauli kelurga sendiri (ekstramaritalseks) baik adik, kakak, bahkan ibu dan anaknya sendiri.

c. Semenleven

Semenleven adalah hidup bersama atau berkelompok tanpa ada sedikitpun niat untuk melangsungkan pernikahan. Dasar pijakan mereka adalah kepuasan seksual baik secara suka sama suka atau hanya sekedar memenuhi kebutuhan seksual sesaat. Perilaku seperti ini banyak di temukan di lingkungan kos baik mahasiswa maupun pelajar.

d. Voyeurisme

Voyeurisme adalah perilaku yang mendapat kepuasan hanya dengan melihat aurat orang lain yang sedang terbuka atau tidak sengaja dibuka. Perilaku ini tampak pada kebiasaan mengintip orang mandi dan melihat film atau gambar porno.

e. Fethisisme, dan

Fethisisme adalah perilaku menyimpang yang merasa mendapat kepuasan seksual hanya dengan memegang, memiliki, melihat bendabenda atau pakaian yang sering dipakai wanita seperti pakaian dalam.

f. Pelecehan seks.

Pelecehan seks berarti penghinaan terhadap nilai seksual seseorang yang ada pada tubuhnya. Hal itu dapat berbentuk tindakan, ucapan, 


\section{Barriyati}

Psikoseksual yang Sehat oleh Guru Pembimbing pada Siswa Kelas XI IPA di Sekolah Menengah Atas

Negeri 1 Bunut Hilir Kabupaten Kapuas Hulu

tulisan, gambar, atau gerakan tubuh yang dinilai oleh seseorang wanita menggangu atau merendahkan martabat kewanitaannya, seperti mencolek, meraba, mencium, dan mendekap.

Dari penjelasan menurut para ahli diatas, maka dapat disimpulkan bahwa dampak dari perkembangan psikoseksual yang tidak sehat dapat menyebabkan seseorang melakukan sesuatu hal dibatas normal dan tergolong dalam penyimpangan yang dilarang baik dalam norma sosial dan agama.

\section{Metode Penelitian}

Dalam suatu penelitian diperlukan metode untuk memecahkan masalah. Metode dapat dipahami sebagai suatu strategi, langkah-langkah atau cara yang ditempuh untuk menjawab masalah penelitian. Adapun metode yang digunakan dalam penelitian ini adalah metode deskriptif. Dalam konteks ini, penelitian deskriptif biasanya dilaksanakan untuk menggali pengetahuan dan menerangkan bagian dari rangkaian riset yang menjadi dasar penelitian. Bentuk penelitian menggungakan survei (survey studies). Survei pada umumnya merupakan cara pengumpulan data dari sejumlah unit atau individu dalam waktu (atau jangka waktu) yang bersamaan". Dengan demikian jelas bahwa penelitian ini dilaksanakan dengan cara mengadakan kunjungan atau survei langsung ke SMA Negeri 1 Bunut Hilir, guna menghimpun data-data yang berkaitan dengan pelaksanaan layanan informasi tentang perkembangan psikoseksual yang dilaksanakan oleh guru pembimbing pada siswa kelas XI IPA, kemudian menganalisis dan menafsirkannya hingga diperoleh suatu kesimpulan. Dalam penelitian ini sampel yang diambil sebanyak 36 siswa dari jumlah populasi yang tersedia. Teknik yang digunakan dalam penelitian ini adalah teknik komunikasi tidak langsung yaitu berupa angket. Angket yang digunakan adalah angket tertutup (closed question) dengan tiga pilihan jawaban, yaitu seringkali, kadang-kadang dan tidak pernah.

\section{Hasil Penelitian dan Pembahasan}

Data-data yang diperoleh dari jawaban angket siswa dianalisis secara kuantitatif dengan menggunakan rumus persentase. Hasil kegiatan ini disajikan dalam tabel rekapitulasi hasil angket. Adapun hasil perhitungan persentase sebagaimana tertuang pada Tabel 1: 
TABEL 1

REKAPITULASI HASIL PERSENTASE JAWABAN ANGKET TENTANG

LAYANAN INFORMASI TENTANG PERKEMBANGAN PSIKOSEKSUAL YANG SEHAT OLEH GURU PEMBIMBING PADA SISWA KELAS XI IPA DI SEKOLAH MENENGAH ATAS NEGERI 1 BUNUT HILIR

\begin{tabular}{|c|c|c|c|c|c|c|c|c|c|}
\hline \multirow{2}{*}{\multicolumn{2}{|c|}{ Nomor }} & \multirow{2}{*}{$\begin{array}{c}\text { Uraian Tentang Layanan Informasi Tentang } \\
\text { Perkembangan Psikoseksual Yang Sehat } \\
\text { Pada Siswa }\end{array}$} & \multicolumn{2}{|c|}{ Selalu } & \multicolumn{2}{|c|}{$\begin{array}{l}\text { Kadang- } \\
\text { kadang }\end{array}$} & \multicolumn{2}{|c|}{$\begin{array}{l}\text { Tidak } \\
\text { Pernah }\end{array}$} & \multirow{2}{*}{$\begin{array}{l}\text { Kateg } \\
\text { ori }\end{array}$} \\
\hline & & & $f$ & $\%$ & $f$ & $\%$ & $f$ & $\%$ & \\
\hline \multicolumn{2}{|c|}{1} & $\begin{array}{l}\text { Langkah-langkah yang dilaksanakan oleh guru } \\
\text { pembimbing }\end{array}$ & & & & & & & \\
\hline 1. & 1 & $\begin{array}{l}\text { Layanan informasi tentang perkembangan } \\
\text { psikoseksual, guru pembimbing membuat } \\
\text { jadwal pertemuan }\end{array}$ & 18 & 50.00 & 10 & 27,78 & 8 & 22,22 & Baik \\
\hline 1. & 2 & $\begin{array}{l}\text { Layanan informasi tentang perkembangan } \\
\text { psikoseksual, guru pembimbing } \\
\text { melaksanakannya sesuai jadwal } \\
\end{array}$ & 3 & 8.33 & 19 & 52.78 & 14 & 38.89 & $\begin{array}{c}\text { Cuku } \\
\mathrm{p}\end{array}$ \\
\hline 1. & 3 & $\begin{array}{l}\text { Layanan informasi tentang perkembangan } \\
\text { psikoseksual, guru pembimbing menetapkan } \\
\text { tempat pelaksanaan bersama siswa }\end{array}$ & 6 & 16.67 & 10 & 27.78 & 20 & 55.55 & $\begin{array}{c}\text { Kuran } \\
\text { g } \\
\text { Baik }\end{array}$ \\
\hline 1. & 4 & $\begin{array}{l}\text { Layanan informasi tentang perkembangan } \\
\text { psikoseksual, guru pembimbing mengabsen } \\
\text { siswa }\end{array}$ & 31 & 86.11 & 4 & 11.11 & 1 & 2.78 & Baik \\
\hline 1. & 5 & $\begin{array}{l}\text { Layanan informasi tentang perkembangan } \\
\text { psikoseksual, guru pembimbing mengadakan } \\
\text { penilaian kepada siswa }\end{array}$ & 11 & 30.55 & 15 & 41.67 & 10 & 27.78 & $\begin{array}{c}\text { Cuku } \\
\mathrm{p}\end{array}$ \\
\hline 1. & 6 & $\begin{array}{l}\text { Layanan informasi tentang perkembangan } \\
\text { psikoseksual, guru pembimbing memberikan } \\
\text { hasil penilaian itu kepada siswa }\end{array}$ & 14 & 38.89 & 14 & 38.89 & 8 & 22.22 & Baik \\
\hline \multicolumn{3}{|r|}{ Rata - rata } & & 38.42 & & 33.33 & & 28.25 & Baik \\
\hline \multicolumn{2}{|c|}{2} & $\begin{array}{l}\text { Bentuk kegiatan yang dilaksanakan oleh guru } \\
\text { pembimbing }\end{array}$ & & & & & & & \\
\hline 2. & 1 & $\begin{array}{l}\text { Layanan informasi tentang perkembangan } \\
\text { psikoseksual yang sehat bagi siswa } \\
\text { diselenggarakan dalam bentuk pertemuan } \\
\text { umum yang melibatkan sejumlah besar siswa } \\
\text { dari berbagai kelas }\end{array}$ & 25 & 69.44 & 5 & 13.89 & 6 & 16.67 & Baik \\
\hline 2. & 2 & $\begin{array}{l}\text { Pertemuan umum diselenggarakan di salah } \\
\text { satu ruangan kelas }\end{array}$ & 3 & 8.33 & 17 & 47.22 & 16 & 44.44 & $\begin{array}{c}\text { Cuku } \\
\mathrm{p}\end{array}$ \\
\hline 2. & 3 & $\begin{array}{l}\text { Guru pembimbing juga memberikan tugas- } \\
\text { tugas yang harus dikerjakan }\end{array}$ & 22 & 61.11 & 13 & 36.11 & 1 & 2.78 & Baik \\
\hline 2. & 4 & \begin{tabular}{|l} 
Layanan informasi tentang perkembangan \\
psikoseksual yang sehat bagi siswa \\
dilaksanakan dalam pertemuan didalam kelas
\end{tabular} & 16 & 44.44 & 18 & 50.00 & 2 & 5.56 & $\begin{array}{c}\text { Cuku } \\
\mathrm{p}\end{array}$ \\
\hline 2. & 5 & $\begin{array}{l}\text { Layanan informasi tentang perkembangan } \\
\text { psikoseksual yang sehat bagi siswa } \\
\text { dilaksanakan pertemuan secara individual } \\
\text { diruangan bimbingan dan konseling } \\
\end{array}$ & 21 & 58.33 & 15 & 41.67 & - & & Baik \\
\hline 2. & 6 & $\begin{array}{l}\text { Layanan informasi tentang perkembangan } \\
\text { psikoseksual yang sehat bagi siswa, guru } \\
\text { pembimbing mendatangkan narasumber dari } \\
\text { luar }\end{array}$ & 1 & 2.78 & 12 & 33.33 & 23 & 63.88 & $\begin{array}{c}\text { Kuran } \\
\text { g } \\
\text { Baik }\end{array}$ \\
\hline 2. & 7 & Guru pembimbing sudah tepat memberikan & 13 & 36.11 & 15 & 41.67 & 8 & 22.22 & Cuku \\
\hline
\end{tabular}




\section{Barriyati}

Psikoseksual yang Sehat oleh Guru Pembimbing pada Siswa Kelas XI IPA di Sekolah Menengah Atas Negeri 1 Bunut Hilir Kabupaten Kapuas Hulu

\begin{tabular}{|c|c|c|c|c|c|c|c|c|c|}
\hline & & $\begin{array}{l}\text { layanan informasi tentang perkembangan } \\
\text { psikoseksual secara pribadi }\end{array}$ & & & & & & & $p$ \\
\hline 2. & 8 & $\begin{array}{l}\text { Layanan informasi tentang perkembangan } \\
\text { psikoseksual yang sehat oleh guru } \\
\text { pembimbing dilaksanakan secara individual di } \\
\text { ruang BK }\end{array}$ & 12 & 33.33 & 22 & 61.11 & 2 & 5.56 & $\begin{array}{c}\text { Cuku } \\
\text { p }\end{array}$ \\
\hline 2. & 9 & $\begin{array}{l}\text { Layanan informasi tentang perkembangan } \\
\text { psikoseksual yang sehat, guru pembimbing } \\
\text { memberikan teguran pada siswa yang } \\
\text { bergurau dengan teman sekelas }\end{array}$ & 10 & 27.78 & 11 & 30.55 & 15 & 41.67 & $\begin{array}{c}\text { Kuran } \\
\text { g } \\
\text { Baik }\end{array}$ \\
\hline & & Rata - rata & & 37.97 & & 39.50 & & 22.53 & $\begin{array}{c}\text { Cuku } \\
\text { p }\end{array}$ \\
\hline & 3 & $\begin{array}{l}\text { Materi yang disampaikan oleh guru } \\
\text { pembimbing }\end{array}$ & & & & & & & \\
\hline 3. & 1 & $\begin{array}{l}\text { Guru pembimbing menyampaikan materi } \\
\text { tentang pengertian perkembangan } \\
\text { psikoseksual yang sehat }\end{array}$ & 36 & 100 & - & & - & & Baik \\
\hline 3. & 2 & $\begin{array}{l}\text { Guru pembimbing menyampaikan materi } \\
\text { karakteristik dan faktor-faktor yang } \\
\text { mempengaruhi perkembangan psikoseksual }\end{array}$ & 28 & 77.77 & 7 & 19.44 & 1 & 2.78 & Baik \\
\hline 3. & 3 & $\begin{array}{l}\text { Layanan informasi apakah guru pembimbing } \\
\text { meyampaikan materi perkembangan } \\
\text { psikoseksual yang tidak sehat }\end{array}$ & 24 & 66.66 & 10 & 27.78 & 2 & 5.56 & Baik \\
\hline 3. & 4 & $\begin{array}{l}\text { Layanan informasi tentang perkembagan } \\
\text { psikoseksual yang sehat, apakah guru } \\
\text { pembimbing menjelaskan apa saja tingkah } \\
\text { laku seksual }\end{array}$ & 32 & 88.88 & 3 & 8.33 & 1 & 2.78 & Baik \\
\hline 3. & 5 & $\begin{array}{l}\text { Guru pembimbing menjelaskan bahwa } \\
\text { Psikoseksual di pengaruhi oleh } \\
\text { perkembangan dan pertumbuhan }\end{array}$ & 32 & 88.88 & 3 & 8.33 & 1 & 2.78 & Baik \\
\hline 3. & 6 & $\begin{array}{l}\text { Guru pembimbing menjelaskan Pengalaman } \\
\text { dimasa kanak-kanak dapat mempengaruhi } \\
\text { kepribadian di usia remaja dan dewasa } \\
\text { khsusnya tentang psikoseksual }\end{array}$ & 31 & 86.11 & 3 & 8.33 & 2 & 5.56 & Baik \\
\hline 3. & 7 & $\begin{array}{l}\text { Pemberian layanan informasi, apakah guru } \\
\text { pembimbing menjelaskan vcd dan majalah } \\
\text { porno, internet, novel merupakan factor } \\
\text { penyebab dalam perkembangan psikoseksual } \\
\text { yang tidak sehat }\end{array}$ & 32 & 88.88 & 3 & 8.33 & 1 & 2.78 & Baik \\
\hline 3. & 8 & $\begin{array}{l}\text { Layanan informasi tentang perkembagan } \\
\text { psikoseksual yang sehat, apakah guru } \\
\text { pembimbing menjelaskan proses dalam } \\
\text { psikoseksual }\end{array}$ & 10 & 27.78 & 16 & 44.44 & 10 & 27.78 & $\begin{array}{c}\text { Cuku } \\
\mathrm{p}\end{array}$ \\
\hline 3. & 9 & $\begin{array}{l}\text { Layanan informasi tentang perkembagan } \\
\text { psikoseksual yang sehat, apakah guru } \\
\text { pembimbing menjelaskan bahwa kegiatan } \\
\text { ektra kurikuler dan organisasi merupakan } \\
\text { salah satu karakteristik perkembangan } \\
\text { psikoseksual }\end{array}$ & 31 & 86.11 & 4 & 11.11 & 1 & 2.78 & Baik \\
\hline & & Rata - rata & & 79.00 & & 15.14 & & 5.86 & Baik \\
\hline & 4 & $\begin{array}{l}\text { Metode yang digunakan oleh guru } \\
\text { pembimbing }\end{array}$ & & & & & & & \\
\hline
\end{tabular}




\begin{tabular}{|c|c|c|c|c|c|c|c|c|c|}
\hline 4. & 1 & $\begin{array}{l}\text { Layanan informasi tentang perkembangan } \\
\text { psikoseksual, guru pembimbing memberikan } \\
\text { informasi dengan ceramah }\end{array}$ & 16 & 44.44 & 17 & 47.22 & 3 & 8.33 & $\begin{array}{c}\text { Cuku } \\
\mathrm{p}\end{array}$ \\
\hline 4. & 2 & $\begin{array}{l}\text { Ceramah yang disampaikan oleh guru } \\
\text { pembimbing sesuai dengan meteri tentang } \\
\text { perkembangan psikoseksual yang sehat }\end{array}$ & 23 & 63.88 & 9 & 25.00 & 4 & 11.11 & Baik \\
\hline 4. & 3 & $\begin{array}{l}\text { Layanan informasi tentang perkembangan } \\
\text { psikoseksual, apakah guru pembimbing } \\
\text { mengadakan tanya jawab }\end{array}$ & 29 & 80.55 & 6 & 16.67 & 1 & 2.78 & Baik \\
\hline 4. & 4 & $\begin{array}{l}\text { Layanan informasi tentang perkembangan } \\
\text { psikoseksual, apakah guru pembimbing } \\
\text { mengajukan pertanyaan secara tertulis } \\
\text { kepada siswa }\end{array}$ & 25 & 69.44 & 6 & 16.67 & 5 & 13.89 & Baik \\
\hline 4. & 5 & $\begin{array}{l}\text { Layanan informasi tentang perkembangan } \\
\text { psikoseksual, apakah guru pembimbing } \\
\text { mengajak siswa berdiskusi }\end{array}$ & 29 & 80.55 & 7 & 19.44 & - & - & Baik \\
\hline 4. & 6 & $\begin{array}{l}\text { Dalam diskusi, guru pembimbing memberikan } \\
\text { tugas-tugas tentang perkembangan } \\
\text { psikoseksual kepada siswa }\end{array}$ & 17 & 47.22 & 16 & 44.44 & 3 & 8.33 & Baik \\
\hline & & Rata - rata & & 64.34 & & 28.24 & & 7.40 & Baik \\
\hline & & $\begin{array}{c}\text { Rata - rata } \\
\text { Keseluruhan Aspek }\end{array}$ & & 54,94 & & 29,05 & & 16,01 & Baik \\
\hline
\end{tabular}

Memperhatikan

rata-rata

keseluruhan aspek pada Tabel 1 di atas yang menunjukkan angka 54,94 untuk jawaban "Selalu", 29,05 menjawab "Kadang-kadang" dan 16,01 menjawab "Tidak Pernah", maka dapat di pahami bahwa secara keseluruhan layanan informasi tentang perkembangan psikoseksual yang sehat oleh guru pembimbing pada siswa kelas XI IPA di SMA Negeri 1 Bunut Hilir dikategorikan "Baik". Jika dilihat lebih rinci pada aspekaspeknya, maka dapat dipaparkan bahwa:

1. Langkah-langkah yang dilaksanakan oleh guru pembimbing dalam pemberian layanan informasi tentang perkembangan psikoseksual yang sehat pada siswa kelas XI IPA tergolong "Baik".

Langkah-langkah yang dilaksanakan oleh guru pembimbing dalam pemberian layanan informasi tentang perkembangan psikoseksual yang sehat, meliputi: persiapan dan perencanaan, pelaksanaan, evaluasi, tindak lanjut, laporan. Tiga dari enam aspek yang ditanyakan masuk kategori baik.

2. Bentuk kegiatan yang dilaksanakan oleh guru pembimbing dalam pemberian layanan informasi tentang perkembangan psikoseksual yang sehat pada siswa kelas XI IPA tergolong "Cukup". 


\section{Barriyati}

Psikoseksual yang Sehat oleh Guru Pembimbing pada Siswa Kelas XI IPA di Sekolah Menengah Atas Negeri 1 Bunut Hilir Kabupaten Kapuas Hulu

Bentuk kegiatan yang dilaksanakan oleh guru pembimbing dalam pemberian layanan informasi tentang perkembangan psikoseksual yang sehat, meliputi: pertemuan umum, pertemuan klasikal, pertemuan kelompok, pertemuan pribadi (individual). Dari sembilan aspek yang ditanyakan empat aspek tergolong cukup, tiga aspek tergolong baik dan dua aspek tergolong kurang baik.

3. Materi yang disampaikan oleh guru pembimbing dalam pemberian layanan informasi tentang perkembangan psikoseksual yang sehat pada siswa kelas XI IPA tergolong "Baik"

Materi yang disampaikan oleh guru pembimbing dalam pemberian layanan informasi tentang perkembangan psikoseksual yang sehat, meliputi: perkembangan psikoseksual yang sehat, karakteristik perkembangan psikoseksual yang sehat, faktor-faktor yang mempengaruhi perkembangan. Dari sembilan aspek yang ditanyakan delapan aspek tergolong baik dan satu aspek tergolong cukup.

4. Metode yang digunakan oleh guru pembimbing dalam pemberian layanan informasi tentang perkembangan psikoseksual yang sehat pada siswa kelas XI IPA tergolong "Baik".

\section{KESIMPULAN}

Berdasarkan hasil analisis data angket dan wawancara, maka dapat disimpulkan bahwa pelaksanaan layanan informasi tentang perkembangan psikoseksual yang sehat oleh guru pembimbing pada siswa kelas XI IPA di SMA Negeri 1 Bunut Hilir telah di laksanakan dengan kategori "Baik".

\section{DAFTAR PUSTAKA}

Gerald Corey (alih bahasa E. Koeswara, 2003). Teori dan Praktek Konseling dan Psikoterapi, Bandung: PT. Refika Aditama.

Kartini Kartono, (1981), Kamus Lengkap Psikologi, Jakarta: Rajawali Press

Latipun, (2001). Psikologi Konseling, Malang: Universitas Malang

M. Asrori, (2005), Perkembangan Peserta Didik, Malang: Wineka Media

Prayitno, dkk. (1998). Pelayanan Bimbingan dan Konseling di Sekolah Menengah Umum (SMU), Jakarta: Ghalia Indonesia. 